answered by the fact that, according to Mr. Hill, the epochs of heaviest winter rain are approximately those of highest mean annual temperature.

E. DOUgIas ARCHIBALI

\section{Distribution of the Black Rat}

Mr. Middleton's letter in Nature, vol. xix. p. 460 , induced me to inquire whether the black rat still occurs in Dresden, the museum under my care possessing several specimens, which were procured on the spot several years ago. The streets where this rat then occurred being known to me, viz.; Meissener strasse, Alaun-gasse, Königsbrücker-strasse, all on the right bank of the Elbe, in Dresden-Neustadt. I inquired in many houses, of the Elbe, in Dresden-Neusard for a specimen, but hitherto in in vain. town, in the direction of the last of the above-named streets, I had traps put there, but also in vain; only the brown rat, $M u$ s decumanus, could be procured.

Every two years a general rat poisoning being ordered by the magistrate of the town, I shall wait till the next one (March, 1880), and then try to state whether Mus rattus still lives in Dresden, as it no doubt lived here several years ago.

The museum possesses besides specimens from Mithlhausen, in Thuringia, and a series from Saxe-Altenburg; in the latter country I do not know the exact locality, the man-a dealer-who sent them, being very mysterious on this point, but I have in dubitable evidence that it still lives there, and even is not rare on some spots. Knowing that it occurred some time ago in the brewery of Blankenhain Castle, near Crimmitzschau, in Saxony, $I$ inquired there, but got the answer that for two years it has been replaced by $M$. decumanus.

Therefore, I am not sure that $M$. rattus still lives in the kingdom of Saxony, but I am sure that it cccurs in the Saxon Duchies. I shall publish the results of my further inquiries in case they are successful.

From the Malay Archipelago I bronght $M$. decumanus, but not $M$. rattus. I got specimens from North and South Celebes, besides other localities, but as the Mures in my collections are not yet definitely determined, I cannot give more particulars now.

Royal Zoological Museum, Dresden, May 3

A. B. MEYER

\section{Mice and Beetles}

PERMTT me to ask, through the medium of your columns, if it is known whether mice kill the common kitchen blackbeetle. I have been unable to find anything bearing upon this subject, but having observed that there is an apparent reduction in the number of beetles, or at least no increase in number while the mice are permitted to live, and also that the mice do not touch any articles of focd in the kitchen, where they are somewhat numerous, I have been led to think that they prey on the beetles in some way.

W. WORBY BEAUMONT

\section{The Cause of Thunder}

I HAVE lately seen it stated in a text-book npon electricity and magnetism that the phenomenon of thunder is not fully accounted for by any theory as yet brought forward. Whether this be so or not I am not sufficiently acquainted with the subject to say. I believe the commonly accepted theory is that a vacuum is created in the path of the electric spark and that the subsequent in-rush of the air produces the detonation. If, however, it be allowed that the electric spark is not a material substance, but merely a natural force or mode of motion, the possibility of this theory is at once disposed of.

It is a well-known fact that the passage of electricity in a high state of tension, through a mixture of oxygen and hydrogen, not only causes an explosion, but also or oxygen and hydrogen, not and it seems to me that, given the existence of free oxygen and hydrogen in the region of the electric disturbance, the phenomenon of thunder is sufficiently accounted for.

Whether the normal amount of hydrogen in the air is sufficient to cause the stupendous noise of thunder $\mathrm{I}$ am not competent to judge, but if not $I$ would suggest that the $I$ am not competent to mal amount might be accounter for the presence of an abnortrolysis, which would probably for by the process of the electrolysis, which would probably occur between the two foles of the rupture of the circuit the tension became so great as to cause a spark. I would encectric thunder-clap is immediately followed by an increase in the quantity of water deposited in the shape of rain. Does not this point to the formation of water by the explosion of the gases?

As I myself am unable both from want of means and time to investigate the matter, I should be glad to find that someone better qualified had taken the subject in hand. It is a frequent experiment of Dr. Tyndall's to show his audience real clouds; I feel convinced that by following this line of inquiry he could give us a real thunderstorm.

S: A. R.

\section{The April Meteors}

ON the night of the 2oth these meteors were watched for between IOh. $45 \mathrm{~m}$. and IIh. $30 \mathrm{~m}$., after which the stars were obscured by a dense fog. During the $\frac{3}{4} \mathrm{~h}$. of observation 15 shootingstars were counted, of which 4 or 5 only belonged to the shower of Lyrids. These were faint and somewhat slow, with slight trains and short paths. The radiant point conld not be exactly fixed. Of the other meteors three were brilliant $(2=$ Ist mag. and $I=2$ nd mag.), and moved with extreme swiftness from a radiant point at $286^{\circ}+23^{\circ}$. They left bright greenish streaks, and were readily distinguished from the Lyrids, though the radiants lie near together. This new shower near $\boldsymbol{\beta}$ Cygni (Albireo) appears to form an important display at this epoch. I saw several bright, rapid meteors from it on April 20-2r last year, and determined the position of its radiant point from a number of shooting-star paths given in Dr. Weiss's two volumes of Anstrian observations at $288^{\circ}+22^{\circ}$ (20 meteors) for the period April I9-23 (see Monthly Notices R.A.S., vol. xxxviii, p. 396). It is further confirmed by a stationary meteor recorded by Palisa, at Troppau on April 19, 1870, at $289^{\circ} 4+26^{\circ} 4$, and it will be advisable to look out specially for this prominent shower of swift, streak-leaving meteors during future returns of the Lyrids. The latter display has quite failed during the last $f \in W$ years.

Ashleydown, Bristol, April 22

W. F. DENNING

\section{Salmo salar and the Schoodic Salmon}

UNDER date of March $\mathbf{1 3}$, in the course of remarks on a late report of the U.S. Commissioner of Fish and Fisheries, you express a wish for an explanation of the fact that a sea-going salmon (Salmo salar) was found among the Schoodic " "landlocked" salmon. I take pleasure in supplying the explanation. The fish referred to were taken in Grand Lake Stream, which connects two of the Schoodic lakes, tributary to the St. Croix River, which discharges into an arm of the sea on the border between the United States and Canada. Before the obstruction of the St. Croix by mill-dams, there was nothing to prevent the ascent of the sea-going salmon to this stream, and it is among the traditions of the aborigines that they were formerly often taken here along with the small "land-locked" or fresh-water salmon. The sea-salmon they called Pl-láhm; the land-locked, Tag-e-wáh-nàhn; and though for many years the sea-salmon were almost wholly prevented from ascending the river by the mill-dams, they have not been entirely exterminated, and the upper waters have been rendered in a degree accessible to the remnant by means of fish-ways constructed within a few years.

7 he specimen taken was, at the close of the season, set free with the other captured fish, and doubtless returned to sea.

I will add that the latest studies of American ichthyologists on the subject have led to the conclusion that the Schoodic and other "land-loclied" salmon are specifically identical with Salmo salar (vide Jordan, "Manual of the Vertebrates of the Northern United States," 1878, p. 357).

Grand Lake Stream,

Maine, U.S.A., April 9

G. AtKins, to the U.S. Commissioner Fish and Fisheries

\section{Intellect in Brutes}

A FEW months ago I made the acquaintance of a dog, which, I think, is worthy of a place among the dogs, and cats, and rats, and mules that are helping the pages of NATURE to determine the degree and kind of animal intelligence.

"Priest's" is a hotel on the way from the Calaveras Grove of Big.trees to the Yosemite. In former years, on the arrival of the stage, the landlady would send the dog to the poultry yard to catch chickens for the tourists' dinner. Now the dog "takes time by the forelock." The stage is due at six o'clock. Abont 